Annu Rev Pharmacol Toxicol. 2013 ; 53: . doi:10.1146/annurev-pharmtox-010611-134648.

\title{
Pharmacology of Iron Transport
}

\author{
Shaina L. Byrne, Divya Krishnamurthy, and Marianne Wessling-Resnick \\ Department of Genetics and Complex Diseases, Harvard School of Public Health, Boston, \\ Massachusetts 02115 \\ Marianne Wessling-Resnick: wessling@hsph.harvard.edu
}

\begin{abstract}
Elucidating the molecular basis for the regulation of iron uptake, storage, and distribution is necessary to understand iron homeostasis. Pharmacological tools are emerging to identify and distinguish among different iron transport pathways. Stimulatory or inhibitory small molecules with effects on iron uptake can help characterize the mechanistic elements of iron transport and the roles of the transporters involved in these processes. In particular, iron chelators can serve as potential pharmacological tools to alleviate diseases of iron overload. This review focuses on the pharmacology of iron transport, introducing iron transport membrane proteins and known inhibitors.
\end{abstract}

\section{Keywords}

hepcidin; hemochromatosis; transferrin; DMT1; NTBI

\section{INTRODUCTION}

Iron is central to DNA and ATP synthesis as well as oxygen transport and a variety of other critical enzymatic and nonenzymatic processes. Iron's catalytic utility arises from its two oxidation states, which interconvert through one-electron oxidation-reduction reactions. However, ferric $\left(\mathrm{Fe}^{3+}\right)$ iron is virtually insoluble in aqueous solution at neutral $\mathrm{pH}$ (concentrations cannot exceed $10^{-17} \mathrm{M}$ ), and ferrous $\left(\mathrm{Fe}^{2+}\right.$ ) iron is highly toxic. If left free in solution, $\mathrm{Fe}^{2+}$ reacts with molecular oxygen and forms the potent hydroxyl radical $\left(\mathrm{OH}^{\bullet}\right)$ through Fenton chemistry $(1,2)$.The reactive oxygen species (ROS) generated can then cause extensive damage to DNA, proteins, and lipids (3). Because of its redox-active nature and insolubility under physiological conditions, the transport of iron is complex. Proteins or small-molecule chelators are often necessary to shuttle iron within cells and between tissues of the human body.

Both surplus and deficiency of this transition metal lead to human pathologies associated with oxidative stress, iron deficiency anemia, or impaired immune function. Maintenance of systemic iron balance in the body requires tight regulation of iron homeostasis $(3,4)$. There does not appear to be a regulated physiologic pathway to excrete excess iron, and the primary mechanism of controlling iron levels in the body is thought to be the regulation of its intake (5). Elucidating the molecular basis for the regulation of mammalian iron uptake, storage, and distribution is necessary to understand iron homeostasis. Unfortunately, the lack

Copyright (C 2013 by Annual Reviews. All rights reserved DISCLOSURE STATEMENT

The authors are not aware of any affiliations, memberships, funding, or financial holdings that might be perceived as affecting the objectivity of this review. 
of pharmacological tools has hampered progress in identifying the pathways, regulatory mechanisms, and connections among iron transport networks (Figure 1). Nonetheless, emerging technologies such as chemical genetic screening have led to the discovery of small-molecule compounds that modulate different pathways of cellular iron uptake. This review focuses on the pharmacology of iron transport in mammalian systems, introducing the membrane proteins involved and some known transport inhibitors.

\section{IRON TRANSPORTERS AND MECHANISMS OF IRON UPTAKE}

\section{Transferrin and Transferrin Receptors}

Iron is acquired by most mammalian cells through receptor-mediated endocytosis of the serum protein transferrin (Tf). Diferric Tf binds to the Tf receptor-1 (TfR1) on the cell surface at the neutral $\mathrm{pH}$ of the blood. TfR1 is a homodimer of 90-kDa subunits in a complex with the major histocompatibility complex (MHC) class I-like molecule HFE and $\beta_{2}$-microglobulin (6). HFE defects are associated with hereditary hemochromatosis (HH) (7). Whereas TfR 1 is ubiquitously expressed, its closely related homolog TfR 2 has a more restricted distribution and predominates in the liver $(8,9)$. Defects in TfR2 are also associated with $\mathrm{HH}$ (10). Once internalized, TfR1-Tf is delivered to endosomes, wherein iron is released owing to the low $\mathrm{pH}$ of these endosomal compartments. The acidic environment stabilizes the binding of apotransferrin (apo-Tf) to its receptor (11), and the ligand-receptor complex recycles back to the cell surface, where apo-Tf dissociates from the receptor at neutral $\mathrm{pH}(12)$.Mechanistically, transport of iron released from $\mathrm{Tf}$ across endosomal membranes involves the reduction of $\mathrm{Fe}^{3+}$ to $\mathrm{Fe}^{2+}$ (13-15), a function provided by the ferrireductase Steap3 (16). In the so-called kiss-and-run hypothesis, endosomes bearing Tf directly deliver cargo iron to mitochondria for heme biosynthesis (17). Still other membrane transporters may transfer iron out of the endosomal-lysosomal system directly into the labile iron pool of the cytosol, including divalent metal transporter-1 (DMT1) (18), ZRT/IRT-like protein 14 (Zip14) (19), and transient receptor potential mucolipin 1 (TRPML1) (20).

\section{Divalent Metal Transporter-1}

DMT1 (Slc11a2) was first identified to be involved in iron assimilation because defects in its gene produce microcytic anemia in the $m k$ mouse, a genetic model with defective dietary iron absorption (21). DMT1, a member of the Nramp family of metal transporters (22), is a 62-kDa protein that has 12 predicted membrane-spanning domains with intracellular $\mathrm{N}$ and $\mathrm{C}$ termini (23). The functional activity of DMT1 has been best characterized using exogenous expression in Xenopus oocytes (24). DMT1 is a proton-coupled symporter with a stoichiometry of $1 \mathrm{Fe}^{2+}: 1 \mathrm{H}^{+}$and with apparent affinities of 6 and $1-2 \mu \mathrm{M}$, respectively (24).Membrane-spanning domains 1 and 6 play a key role in proton-dependent metal transport (25-27). The transporter interacts with several different divalent metals, and it influences both manganese and iron metabolism (28). DMT1 protein and mRNA are most abundant in the duodenum, consistent with a function in intestinal iron absorption $(24,29)$. Reduction of $\mathrm{Fe}^{3+}$ at the brush border by duodenal cytochrome B precedes translocation of $\mathrm{Fe}^{2+}$ by DMT1 across the apical membrane (30).

A remarkable link between intestinal iron import and Tf iron assimilation resulted from the discovery that DMT1 is mutated in the Belgrade rat (18). Defects in Tf-bound iron uptake were well characterized for this animal model of anemia. Although Tf is internalized by Belgrade reticulocytes, iron fails to be captured because of a loss of transmembrane transport activity in the endosome (31-34). The observation that the pH-dependentDMT1 transporter localizes to acidic endosomal compartments supports its role in this process (35, 36).Notably, inactivating mutations of the $m k$ mouse and Belgrade rat reside at the same 
residue (G185R). Numerous loss-of-function mutations also have been identified in human patients (R416C, G1221V, $\Delta$ V114, G75R) (37-40).

\section{Zip14 and Zip Family Members}

Although there is strong evidence for the role of DMT1 in endocytic iron transport, mice that are deficient in Steap3 (41) or DMT1 (42) remain able to import liver iron. Moreover, certain cells also import non-transferrin-bound iron (NTBI) directly across the plasma membrane (43). This pathway contributes to the pathology of hemochromatosis, as evidenced by NTBI that is found in serum from patients (44). In addition, NTBI is found in infant cord blood and plasma (45), in patients with hepatic failure (46), in patients undergoing chemotherapy (47), in arthritic patient synovial fluid (48), and in cerebral spinal fluid (49). Recent studies suggest that Zip14 (Slc39a14) is a divalent metal transporter that not only facilitates iron uptake from Tf but also functions as an NTBI importer.

Zip family members were first identified as zinc transporters in yeast $(50,51)$ and ironregulated metal transporters in plants (52). Zip14 functions in both zinc and iron transport $(53,54)$, and several Zip family members also interact with metals other than zinc (55). Zip proteins have eight predicted membrane-spanning domains. Zip14 belongs to the LIV-1 subfamily, although the initial histidine in conserved membrane-spanning domain 4 (HEXPHEXGD) is replaced with a glutamic acid residue (EEXPHEXGD); this substitution may contribute to Zip14's broader metal transport range. Mechanistically, iron and zinc are recognized and translocated by Zip14 through different mechanisms (54). Exogenous expression of Zip14 in HepG2 cells not only stimulates NTBI uptake but also increases acquisition of iron from Tf (19). Conversely, knockdown of Zip14 by siRNA decreases Tfbound iron uptake (19). Thus, both DMT1 and Zip14 may play redundant roles in the cellular uptake of Tf-bound and NTBI uptake pathways.

\section{Iron-Transporting Channels}

Calcium uptake and, by extension, calcium channels are of interest in the context of iron uptake. From a nutritional point of view, dietary calcium reduces iron bioavailability (56). Altered cellular calcium levels suppress both NTBI uptake pathways (57) and Tf-bound pathways (58). L-type calcium channels have been implicated in iron entry under conditions of overload in cardiomyocytes $(59,60)$, whereas $\mathrm{Fe}^{2+}$, in turn, can block voltage-gated calcium currents (61).More recently, Shawki \& Mackenzie (62) examined the interaction between calcium and DMT1 in Xenopus oocytes and hypothesized that although human DMT1 does not mediate calcium uptake, $\mathrm{Ca}^{2+}$ is a low-affinity noncompetitive inhibitor of this iron transporter. Interestingly, the G185R mutation in the DMT1 gene, which leads to defective iron assimilation in Belgrade $(b)$ rats and microcytic $m k$ mice, confers calcium transport activity to DMT1 (63).

Members of the TRPML superfamily transport $\mathrm{Fe}^{2+}$ and are located in endolysosomes. TRPML has six predicted membrane-spanning domains with intracellular (cytosolic) $\mathrm{N}$ and C termini (64). In particular, a role for TRPML1 as a channel for iron release across late endosomes and lysosomes has been described (20). Mutations in this transient receptor potential channel are associated with mucolipidosis, and patients carrying these disease alleles display not only neurodegenerative impairments but also iron deficiency anemia. TRPML1 likely enhances the efficiency of iron uptake from the Tf-bound pathway, either working in conjunction with or in a pathway that is redundant with that of DMT1 and/or Zip14 (Figure 1). Ineffective iron transport caused by disease mutations results in lower cytosolic iron levels and increased lysosomal iron pools (20). 


\section{Iron Export by Ferroportin}

Although multiple import pathways have been identified, only one iron export pathway is known. The body's conservation of iron suggests that export would be restricted. Three independent studies seeking to elucidate the molecular basis for iron export led to the identification of the same factor: Ferroportin was found through positional cloning of a defective gene in anemic zebrafish (65), iron-regulated protein-1 (Ireg1) was characterized through subtractive hybridization of mRNAs induced in $h p x$ (hypotransferrinemic) mice (66), and metal transport protein-1 (MTP1) was cloned by construction of a library enriched for iron-responsive protein-1 (IRP-1) binding (67). There is some agreement that this transporter-also known by its mouse and human gene names, SIc39A1 (68) and SLC11A3 (69) - is best described by the name ferroportin.

Ferroportin is highly conserved; human, mouse, and rat clones are $90-95 \%$ homologous at the protein level (70). The 62-kDa protein has nine predicted membrane-spanning domains and a cytoplasmically positioned $\mathrm{N}$ terminus. The protein localizes to the basolateral membrane of polarized cells (66), supporting the idea that it functions in the assimilation of dietary iron by exporting the metal from intestinal enterocytes. The copper-containing ferroxidase hephaestin assists by converting $\mathrm{Fe}^{2+}$ to $\mathrm{Fe}^{3+}$, which is then bound by Tf (Figure 1). Furthermore, ferroportin is found in macrophages of the reticuloendothelial system, and it exports iron recycled after erythrophagocytosis (71). Type IV HH or ferroportin disease arises from mutations in this gene.

\section{IRON TRANSPORT INHIBITORS AND STIMULATORS}

\section{Antioxidants: Ebselen and PDTC}

Ebselen (2-phenyl-1,2-benzisoselenazol-3[2H]-one) is a lipid-soluble, selenium-containing compound that has neuroprotective effects against ischemic stroke $(72,73)$. Its pharmacological profile is due in large part to its antioxidant properties, and studies have shown that ebselen can (a) mimic glutathione peroxidase activity (74), (b) inhibit several inflammatory enzymes by thiol modification $(74)$, and $(c)$ reduce thioredoxin $(75,76)$. Interestingly, this selenazol decreased iron levels in the hearts of iron-overloaded mice (77), thus showing promise as an inhibitor of iron uptake. A fluorescence-based chemical genetic screen subsequently identified ebselen as an antagonist of DMT1 (78). Ebselen inhibits DMT1 ${ }^{55} \mathrm{Fe}^{2+}$ uptake activity with an $\mathrm{IC}_{50}$ of $0.22 \mu \mathrm{M}$, but it has no effect on ${ }^{54} \mathrm{Mn}$ uptake, despite the fact that $\mathrm{Mn}^{2+}$ is a known DMT1 transport substrate (24). Additionally, ebselen does not inhibit Tf-bound uptake; therefore, its effects appear specific to transport of ferrous iron. Pyrrolidinedithiocarbamate (PDTC) is a second antioxidant that inhibits DMT1 $\left(\mathrm{IC}_{50}=\right.$ $1.54 \mu \mathrm{M})$. Both compounds affect cellular redox status because they increase cellular levels of glutathione in their reduced forms. Cytosolic iron levels are balanced between the ferric and ferrous forms (79), and the antioxidants perturb this equilibrium. Such compounds could promote a change in redox environment, potentially targeting ferrireductases involved in iron uptake pathways (80) (Table 1).

\section{Calcium Channel Blockers}

Effects of L-type calcium channel blockers on iron transport have been examined (81). Among antagonists tested, nicardipine, diltiazem, verapamil, and cinnarizine displayed little to no inhibition, whereas nifedipine [3,5-dimethyl 2,6-dimethyl-4-(2-nitrophenyl)-1,4dihydropyridine-3,5-dicarboxylate] strongly stimulated NTBI uptake but not Tf-bound iron uptake. Nifedipine is light sensitive, and a biologically active photodegradation product was ultimately shown to be the active form as a nitrosophenylpyridine derivative (82). Because this compound also increased iron efflux, photodegraded nifedipine was hypothesized to act as a lipophilic iron ionophore that shuttles $\mathrm{Fe}^{2+}$ across the cell membrane. 
Ludwiczek et al. (83) described new pharmacological effects of nifedipine and another Ltype channel blocker, niguldipine, on DMT1. Mice treated with nifedipine had decreased serum iron, which correlates with a DMT1 genotype. Nifedipine-mediated DMT1 activation was proposed to mobilize excess iron from liver and to increase excretion by the kidneys and thus be of possible clinical benefit to patients with iron overload disorders. However, the effects were attributed to nifedipine and not its photodegradation products. Conflicting results were obtained when Mackenzie, Garrick, and colleagues (84) rigorously examined nifedipine effects on DMT1 in vitro. In their study, the parent compound did not increase DMT1-mediated transport of ${ }^{59} \mathrm{Fe}$ or ${ }^{54} \mathrm{Mn}$. When photodegraded nifedipine was tested, it weakly stimulated iron uptake, but it had no effect on manganese uptake. Thus, the direct effect of nifedipine and/or its photodegradation products on DMT1 activity remains controversial.

\section{NSC306711/Ferristatin}

NSC306711 was also identified from a fluorescent cell-based assay in a search for NTBI uptake inhibitors (85). NSC306711 blocks DMT1 transport activity with $\mathrm{IC}_{50} \sim 14.7 \mu \mathrm{M}$ (86). This compound is a polysulfonated dye with two copper centers that do not influence drug activity. NSC306711 functions as a competitive and reversible inhibitor of DMT1 and does not perturb cellular redox status. Other polysulfonated compounds, structurally related to NSC306711 but lacking the copper centers, also interfere with DMT1 iron uptake, warranting additional work on their mechanism of action and potential use in remediating iron overload (86).

Lane et al. (87) used this compound to define how astrocytes import NTBI. Two independent mechanisms of astrocyte NTBI uptake are observed in the presence or absence of ascorbate. Ascorbate-depleted cells display a $\mathrm{Fe}^{3+}$-selective pathway, whereas ascorbatereplete cells take up $\mathrm{Fe}^{2+}(88)$. Ascorbate loading of astrocytes markedly enhances iron accumulation, presumably due to reduction of $\mathrm{Fe}^{3+}$ to $\mathrm{Fe}^{2+}$ by ascorbate exported to the medium. NSC306711 blocks iron uptake by ascorbate-replete cells, and, on the basis of high expression of DMT1 in astrocytic endfeet $(89,90)$, Lane et al. (87) concluded that DMT1 is the transporter that facilitates NTBI import into ascorbate-replete astrocytes.

NSC306711 also blocks Tf-bound iron uptake with $\mathrm{IC}_{50} \sim 20 \mu \mathrm{M}$ (85). This is not altogether surprising because DMT1 is also involved in the release of Tf-bound iron from endosomes (18). However, the mechanism of inhibition was unexpected because NSC306711 induced internalization and degradation of TfR1. TfR1 trafficking has been well studied as a classic form of clathrin-mediated endocytosis (91), but siRNA knockdown of clathrin expression does not interfere with TfR 1 downregulation by NSC306711. Instead, the action of this compound is sensitive to cholesterol depletion (92), and treatment of cells with nystatin and filipin (reagents that readily interact with cholesterol) blocks inhibition and degradation of TfR1 induced by NSC306711 (92). Because this compound affects TfR1 uptake through a cholesterol-dependent pathway, the name ferristatin was coined. However, a generalized effect on lipid rafts is not observed, and the stability of flotillin (93), a lipid raft resident protein, is not altered. Collectively, these findings revealed an unexpected role for lipid rafts in TfR1 trafficking.

\section{Lysosomotropic Agents}

Weak bases can penetrate and accumulate in acidic compartments of the cell such as lysosomes and endosomes, increase their $\mathrm{pH}$, and disrupt Tf-bound iron uptake (91, 94-96). Lysosomotropic agents such as $\mathrm{NH}_{4} \mathrm{Cl}, \mathrm{CH}_{3} \mathrm{NH}_{2}$, $n$-butyl amine, $\left(\mathrm{CH}_{3}\right)_{2} \mathrm{NH}$, and chloroquine interfere with Tf-bound iron uptake. Recently, chemical genetic screening resulted in the identification of a novel class of sulfonamides that also blocked endocytic 
uptake of iron via the Tf-TfR pathway (97). These compounds elevate endosomal $\mathrm{pH}$ from 6.4 to 7.0 and inhibit dissociation of iron from $\mathrm{Tf}$ and recycling of receptors to the cell surface. The sulfonamides exhibited proton ionophore activity and blocked the $\mathrm{V}_{1}$ domain of vacuolar ATPase, which maintains the $\mathrm{pH}$ by pumping protons into the intracellular organelle (98).

\section{Hepcidin}

Hepcidin, a peptide hormone that is secreted primarily by hepatocytes, is an important regulator of iron homeostasis $(99,100)$. Body iron stores, inflammation, erythropoiesis, bone morphogenic proteins, HFE, hemojuvelin, and TfR2 modulate its gene expression (101). Dysregulated hepcidin production contributes to hemochromatosis, hepatitis C, and iron-loading anemias (102-105). Bioactive hepcidin is a 25-residue-long cysteine-rich peptide that results from enzymatic cleavage of the 84-amino acid propeptide originally produced by the liver (106). This liver-derived peptide regulates systemic iron metabolism by functioning at two key stages: inhibiting iron absorption in the small intestine and inhibiting iron release from macrophages by binding to the iron exporter ferroportin. Hepcidin binds directly to ferroportin, which is located on the basolateral membrane of enterocytes and on the surface of macrophages, and induces phosphorylation, internalization, and degradation of the iron export protein (107). Treatment with hepcidin decreases ferroportin levels in both $\mathrm{J} 774$ macrophage cells and bone marrow macrophages $(71,108,109)$. Thus, by downregulating ferroportin and, by extension, cellular iron efflux, hepcidin should function as an inhibitor of iron absorption. However, its mechanism of action in intestinal cells has been the focus of controversy. Several groups have reported that addition of hepcidin to Caco- 2 cells and rat duodenal segments inhibits apical iron uptake and that this inhibition is associated with a significant decrease in DMT1 levels (110-112). Beaumont and coworkers (113) showed that hepcidin-mediated degradation of DMT1 occurs through a proteasomal pathway. Whereas hepcidin induced a decrease in DMT1 levels in these cells, levels of ferroportin remained unchanged. The effect of hepcidin, therefore, appears to be dependent on cell type: In macrophages, hepcidin inhibits iron export by ferroportin degradation; in intestinal cells, it inhibits iron absorption through DMT1 degradation.

\section{Siderophores and Siderocalin}

Naturally occurring iron chelators, siderophores, are secreted by microorganisms to scavenge environmental iron into bioavailable complexes. Pathogenic microbes also utilize siderophores to scavenge iron from bound protein complexes (e.g., transferrin, lactoferrin, hemoglobin) of their mammalian hosts (114). Siderophores are typically grouped into three classes: hydroxamates, catecholates, and hydroxycarboxylates (114). One of the most wellstudied and clinically used siderophores is deferoxamine (DFO; see below).

Hydroxybenzoates and hydroxybenzenes are often found in mammalian serum and urine, suggesting that a mammalian siderophore might function as a small-molecule iron chelator to traffic iron within cells when it is not bound to transport and storage proteins or incorporated into protein functional groups. The mammalian protein siderocalin (also known as Scn-Ngal, lipocalin-2, and 24p3) is a member of the lipocalin family that binds such small organic molecules. Siderocalin binds and sequesters bacterial siderophores such as enterobactin and enterochelin, thereby halting bacterial growth (115). Recently, two groups identified mammalian siderophores that bind to siderocalin and sequester the bound iron. Bao et al. (116) discovered that iron traffics as a siderocalin-catechol complex. Crystal structures show catechol-Fe bound in the calyx of siderocalin, and in vivo studies show that a siderocalin-catechol- Fe complex circulates to provide iron to tissues (most notably, the kidney). Devireddy et al. (117) suggest that siderocalin binds and delivers iron when bound to 2,5-dihydroxybenzoic acid, a mammalian siderophore similar to 2,3-dihydroxybenzoic 
acid, a bacterial siderophore of enterobactin. More needs to be learned about mammalian siderophores and siderophore-binding complexes, but these discoveries suggest that endogenous inhibitors that chelate iron can inhibit transport, target delivery, and regulate metabolism of the host when it is infected.

\section{IRON PHARMACOLOGY AND DISEASE}

\section{Chelation Therapy for Iron Loading}

Several iron chelators have been tested as therapeutic agents to alleviate iron overload (Table 2). The most well studied is DFO, which has been the gold standard for iron overload treatment for $>40$ years. A hexadentate iron chelator (produced by Streptomyces pilosus), DFO binds $\mathrm{Fe}^{3+}$ with high affinity and renders it inactive and unable to produce ROS. DFO also decreases oxidative stress often associated with disease $(118,119)$. However, owing to its hydrophilicity, DFO is poorly absorbed by the gastrointestinal tract and has an extremely short half-life in the plasma of $\sim 12 \mathrm{~min}$ (120). DFO also exhibits antiproliferative properties against aggressive cancers such as neuroblastoma and leukemia. Owing to its lack of membrane permeability and short half-life, improvements are necessary to make this a viable treatment option for both iron overload and cancer patients (119).

Deferiprone, a bidentate hydroxypyridinone that was synthesized and tested in the United Kingdom in the 1980s, is hydrophilic and relatively nontoxic in a variety of cell lines tested (121). A recent review summarizes the clinical trials that employed deferiprone as an ironchelating agent to reduce iron overload (121). However, the safety and/or toxicity of deferiprone alone has been a topic of debate, prompting Motekaitis \& Martell (122) to investigate the redox activity of preformed deferiprone-iron complexes. In vitro studies showed an increase in oxygen radical production at deferiprone:iron ratios less than $3: 1$. To reduce these toxic byproducts, investigators have explored combination therapy of DFO and deferiprone $(119,121)$. The basis of such therapy is that deferiprone can access intracellular compartments, chelating iron and making it available to extracellular DFO, which cannot cross cell membranes. The stable DFO-iron complex is then excreted in the urine. Currently, combination therapy has shown promising results, but long-term safety data are needed.

Deferasirox (ICL670A) is a bis-hydroxyphenyl-triazole tridentate ferric iron chelator that is orally available (123). It is highly lipophilic and mobilizes iron from liver and heart tissue efficiently. In vivo studies in rats and primates concluded that the drug was four to five times better at removing iron than was DFO (124). Clinically, deferasirox has been examined in the largest development program of any iron chelator, incorporating five clinical trials to assess efficacy, safety, and tolerability across several transfusion-dependent anemias (125-129). This drug is currently approved in the United States, the European Union, Switzerland, and elsewhere to treat transfusion-induced iron overload in both pediatric and adult patients and is in clinical trials for treatment of $\beta$-thalassemia, sickle cell disease, myelodysplastic syndromes, Diamond-Blackfan anemia, and other rare anemias.

Two other oral iron chelators are in various stages of clinical trials. Deferitrin is a tridentate chelator that has a half-life of $3-8 \mathrm{~h}$ and is excreted in the feces. Current data suggest that deferitrin is less effective than DFO and that-although evaluations of long-term and combination studies are necessary-it is not likely to suffice as a monotherapy (121). L1NA11, a member of the a- ketohydroxypyridine group of chelators that is currently in Phase I development, is a potent bidentate iron chelator capable of mobilizing iron from transferrin, ferritin, and hemosiderin (130). Increased iron excretion compared with deferiprone and DFO was shown in iron-loaded mice, rats, and rabbits (131). In a subacute toxicity study in rats, $45 \%$ mortality was reported in normal rats and no deaths were 
recorded for iron-loaded rats, suggesting that L1NA11 mobilized iron to toxic low levels in normal rats but offered protection in the iron-loaded rats (131).

\section{Iron Transport and Cancer}

Removal of iron arrests cell proliferation at the $\mathrm{G}_{1} / \mathrm{S}$ phase of the cell cycle (132-134); thus, iron chelation and transport inhibition are appealing prospects for cancer therapy. In general, chelation is more effective when iron is coordinated by "soft" electron donor groups, allowing for the so-called double-punch effect (135). The chelator not only sequesters iron from the tumor cell but also is redox active and can generate ROS, causing extensive cell damage that leads to apoptosis of cancer cells. Thiosemicarbazones are a class of strong antiproliferative iron chelators that bind iron with nitrogen and with sulfur donor groups that permit redox cycling and generation of ROS. 3-Aminopyridine-2-carboxaldehyde thiosemicarbazone (3-AP) entered clinical trials in 2007 (136-138), but many were terminated early owing to adverse side effects and no signs of improvement (137-141). A new series, the 2-hydroxyl-1-naphthylaldehyde-3-thiosemicarbazone (NT) chelators, was synthesized on the basis of information gained from the 3-AP studies (142-145), but compounds with the highest antiproliferative activity had lower iron chelation efficacy and vice versa (144). The di-2-pyridyl thiosemicarbazones (the DpT series) also showed promise against a variety of cancer cell lines. The derivative Dp44mT exhibited the most antiproliferative, iron-chelating, and redox activity, but cardiac fibrosis developed in nude mice when Dp44mT was administered in high dose (146). Another class of 2benzoylpyridine thiosemicarbazones (the BpT series) appears to surpass the DpT series in its antiproliferative and redox properties in cancer cell line studies; this series thus warrants further study (147).

Small molecules that modulate iron transport have also been considered as potential anticancer agents. Because production of ROS by excess iron accrual ultimately results in increased oxidative damage and cell death, a stimulator of iron uptake named LS081, recently identified by chemical genetic screening (148), was tested in various cancer cell lines. LS081 plus $2-10 \mu \mathrm{M}$ of iron increased cellular iron, decreased proliferation, decreased expression of hypoxia-inducible factor (HIF)-1 $\alpha$ and HIF-2a (factors that can drive cancer growth), decreased clonogenicity, and stimulated production of ROS. Elevated ROS might make LS081-treated cells more sensitive to both radiation therapy and other drugs (148). In addition, high levels of HIF-1 $\alpha$ and HIF-2 $\alpha$ are indicators of poor prognosis, and increased intracellular iron could potentially enhance prolyl hydroxylase activity and proteasomal degradation of HIF proteins (148). The mechanism of LS081 action still remains to be determined, but its discovery represents an interesting new approach to cancer treatment.

The Tf-TfR1 endocytic pathway has been exploited as a means to deliver metals and conjugated drugs to cancer cells. Antibodies against TfR1 successfully inhibit human tumor growth in vitro and in vivo by blocking Tf-bound iron entry into cells $(149,150)$. Additionally, although primarily an iron-binding protein, Tf has a diverse metal-binding capacity that has been exploited to deliver to cells therapeutic metal ions such as gallium and indium (133). This approach has been used in both diagnostic and chemotherapeutic treatments of malignancies and neoplasms. Finally, diphtheria toxin conjugated to Tf (TfCRM107; TransMID ${ }^{\mathrm{TM}}$, Xenova Group) has been infused into malignant brain tumors, and Phase I and II trials have provided encouraging results: Antitumor effects were seen in patients resistant to conventional therapy (151).

Lysosomal iron chelation has also been proposed as means of protection against oxidative damage in cancer treatment and other modalities. Lysosomes have a large pool of redoxactive labile iron, making them a target of initial oxidative damage. The large amount of iron present in lysosomes results from autophagy and autophagic degradation of ferritin and 
other iron-containing proteins. Sensitivity to oxidative stress is influenced by ferritin autophagy (152), and use of the soluble iron chelator salicylaldehyde isonicotinoyl hydrazine has been proposed (152). As another example, amifostine has been explored in clinical trials for treatment of non-small-cell lung cancer and several other types of cancer (153-158). The use of this drug, which acts as a radioprotector and lysosomotropic iron chelator (159), has been approved for head and neck cancers to protect against radiationinduced xerostomia (160).

\section{Iron Transport and Neurodegenerative Diseases}

Mitochondrial iron chelation is another organelle-based means of protection for diseases such as Friedreich's ataxia (FA). FA is a severe neurodegenerative disorder that results in mitochondrial iron overload and disrupted iron-sulfur assembly (161). Sensitivity to the FA mutation is rescued with iron chelators (162). Clinically, chelation therapy is problematic because compounds have to specifically target mitochondrial iron to avoid nonspecific iron deficiency anemia. Pyridoxal isonicotinoyl hydrazone (PIH) is one iron chelator that can permeate the plasma membrane as well as the outer and inner mitochondrial membranes and can bind mitochondrial iron (163), and some work has been carried out to advance PIH derivatives to resolve problems with mitochondrial iron loading (reviewed in 164).

Chelation therapy has been explored as a means of neuroprotection, and the brain-permeable VK-28 series of iron chelators has been studied in models of Parkinson's disease (165). Alzheimer's disease is another neurodegenerative disorder that can be improved by chelation therapy (166). In vitro studies show that pretreatment of $\beta$-amyloid (a plaquecausing agent) with DFO reduced the cytotoxicity of $\beta$-amyloid in an iron-dependent manner. (167). Recently, the Alzheimer's disease $\beta$-amyloid precursor protein was shown to have a ferroxidase activity associated with ferroportin iron export (168) and to be regulated by iron through an atypical iron-responsive element in the $5^{\prime}$ untranslated region of its mRNA (169). Both activities appear to be targets for disruption of iron transport $(170,171)$.

\section{Use of Natural Products}

Emerging information from the use of natural products has also begun to expand our understanding of iron transport. The anticancer properties of curcumin, an ingredient of the spice turmeric, include its biological activity as an iron chelator, and it induces iron depletion in vivo (172). Silybin, a polyphenol in milk thistle, reduces iron absorption in patients with HH (173). The antioxidant extract of Ginkgo biloba leaves (EGb761) prevents iron-dependent peroxidation of polyunsaturated fatty acids (174). These and other new developments in the pharmacology of iron transport hold great promise in combating a variety of diseases.

\section{Acknowledgments}

M.W.-R. is supported by National Institutes of Health grants R01 DK064750, R01 ES014638, R21 DA025573, RC1 DK086774, and R03 DA027030.

\section{Glossary}

$\begin{array}{ll}\text { ROS } & \text { reactive oxygen species } \\ \text { Tf } & \text { transferrin } \\ \text { TfR1/TfR2 } & \text { transferrin receptor-1 and }-2 \\ \text { HH } & \text { hereditary hemochromatosis }\end{array}$


DMT1 divalent metal transporter-1

Zip14 ZRT/IRT-like protein 14

TRPML1 transient receptor potential mucolipin 1

NTBI non-transferrin-bound iron

\section{LITERATURE CITED}

1. Aisen P, Listowsky I. Iron transport and storage proteins. Annu. Rev. Biochem. 1980; 49:357-393. [PubMed: 6996567]

2. Wessling-Resnick M. Biochemistry of iron uptake. Crit. Rev. Biochem. Mol. Biol. 1999; 34:285314. [PubMed: 10565676]

3. Hentze MW, Muckenthaler MU, Andrews NC. Balancing acts: molecular control of mammalian iron metabolism. Cell. 2004; 117:285-297. [PubMed: 15109490]

4. Garrick M. Human iron transporters. Genes Nutr. 2011; 6:45-54. [PubMed: 21437029]

5. Wessling-Resnick M. Iron transport. Annu. Rev. Nutr. 2000; 20:129-151. [PubMed: 10940329]

6. Feder JN, Penny DM, Irrinki A, Lee VK, Lebron JA, et al. The hemochromatosis gene product complexes with the transferrin receptor and lowers its affinity for ligand binding. Proc. Natl. Acad. Sci. USA. 1998; 95:1472-1477. [PubMed: 9465039]

7. Feder JN, Gnirke A, Thomas W, Tsuchihashi Z, Ruddy DA, et al. A novel MHC class I-like gene is mutated in patients with hereditary haemochromatosis. Nat. Genet. 1996; 13:399-408. [PubMed: 8696333]

8. Kawabata H, Yang R, Hirama T, Vuong PT, Kawano S, et al. Molecular cloning of transferrin receptor 2: a new member of the transferrin receptor-like family. J. Biol. Chem. 1999; 274:2082620832. [PubMed: 10409623]

9. Kawabata H, Germain RS, Ikezoe T, Tong X, Green EM, et al. Regulation of expression of murine transferrin receptor 2. Blood. 2001; 98:1949-1954. [PubMed: 11535534]

10. Camaschella C, Roetto A, Cali A, De Gobbi M, Garozzo G, et al. The gene TFR2 is mutated in a new type of haemochromatosis mapping to 7q22. Nat. Genet. 2000; 25:14-15. [PubMed: 10802645]

11. Klausner RD, Ashwell G, van Renswoude J, Harford JB, Bridges KR. Binding of apotransferrin to K562 cells: explanation of the transferrin cycle. Proc. Natl. Acad. Sci. USA. 1983; 80:2263-2266. [PubMed: 6300904]

12. Richardson DR, Ponka P. The molecular mechanisms of the metabolism and transport of iron in normal and neoplastic cells. Biochim. Biophys. Acta. 1997; 1331:1-40. [PubMed: 9325434]

13. Nunez MT, Gaete V, Watkins JA, Glass J. Mobilization of iron from endocytic vesicles: the effects of acidification and reduction. J. Biol. Chem. 1990; 265:6688-6692. [PubMed: 2324097]

14. Watkins JA, Nunez MT, Gaete V, Alvarez O, Glass J. Kinetics of iron passage through subcellular compartments of rabbit reticulocytes. J. Membr. Biol. 1991; 119:141-149. [PubMed: 2046086]

15. Oshiro S, Nakajima H, Markello T, Krasnewich D, Bernardini I, Gahl WA. Redox, transferringindependent, and receptor-mediated endocytosis iron uptake systems in cultured human fibroblasts. J. Biol. Chem. 1993; 268:21586-21591. [PubMed: 8408010]

16. Ohgami RS, Campagna DR, Greer EL, Antiochos B, McDonald A, et al. Identification of a ferrireductase required for efficient transferrin-dependent iron uptake in erythroid cells. Nat. Genet. 2005; 37:1264-1269. [PubMed: 16227996]

17. Zhang AS, Sheftel AD, Ponka P. Intracellular kinetics of iron in reticulocytes: evidence for endosome involvement in iron targeting to mitochondria. Blood. 2005; 105:368-375. [PubMed: 15331447]

18. Fleming MD, Romano MA, Su MA, Garrick LM, Garrick MD, Andrews NC. Nramp2 is mutated in the anemic Belgrade $(b)$ rat: evidence of a role for Nramp2 in endosomal iron transport. Proc. Natl. Acad. Sci. USA. 1998; 95:1148-1153. [PubMed: 9448300] 
19. Zhao N, Gao J, Enns CA, Knutson MD. ZRT/IRT-like protein 14 (ZIP14) promotes the cellular assimilation of iron from transferrin. J. Biol. Chem. 2010; 285:32141-32150. [PubMed: 20682781]

20. Dong XP, Cheng X, Mills E, Delling M, Wang F, et al. The type IV mucolipidosis-associated protein TRPML1 is an endolysosomal iron release channel. Nature. 2008; 455:992-996. [PubMed: 18794901]

21. Fleming MD, Trenor CC III, Su MA, Foernzler D, Beier DR, et al. Microcytic anaemia mice have a mutation in Nramp2, a candidate iron transporter gene. Nat. Genet. 1997; 16:383-386. [PubMed: 9241278]

22. Cellier M, Prive G, Belouchi A, Kwan T, Rodrigues V, et al. Nramp defines a family of membrane proteins. Proc. Natl. Acad. Sci. USA. 1995; 92:10089-10093. [PubMed: 7479731]

23. Czachorowski M, Lam-Yuk-Tseung S, Cellier M, Gros P. Transmembrane topology of the mammalian Slc11a2 iron transporter. Biochemistry. 2009; 48:8422-8434. [PubMed: 19621945]

24. Gunshin H, Mackenzie B, Berger UV, Gunshin Y, Romero MF, et al. Cloning and characterization of a mammalian proton-coupled metal-ion transporter. Nature. 1997; 388:482-488. [PubMed: 9242408]

25. Courville P, Urbankova E, Rensing C, Chaloupka R, Quick M, Cellier MF. Solute carrier 11 cation symport requires distinct residues in transmembrane helices 1 and 6. J. Biol. Chem. 2008; 283:9651-9658. [PubMed: 18227061]

26. Xiao S, Li J, Wang Y, Wang C, Xue R, et al. Identification of an "a-helix-extended segment-ahelix" conformation of the sixth transmembrane domain in DMT1. Biochim. Biophys. Acta. 2010; 1798:1556-1564. [PubMed: 20388494]

27. Wang D, Song Y, Li J, Wang C, Li F. Structure and metal ion binding of the first transmembrane domain of DMT1. Biochim. Biophys. Acta. 2011; 1808:1639-1644. [PubMed: 21074515]

28. Chua AC, Morgan EH. Manganesemetabolism is impaired in the Belgrade laboratory rat. J. Comp. Physiol. B. 1997; 167:361-369. [PubMed: 9265748]

29. Canonne-Hergaux F, Gruenheid S, Ponka P, Gros P. Cellular and subcellular localization of the Nramp2 iron transporter in the intestinal brush border and regulation by dietary iron. Blood. 1999; 93:4406-4417. [PubMed: 10361139]

30. Latunde-Dada GO, Van der Westhuizen J, Vulpe CD, Anderson GJ, Simpson RJ, McKie AT. Molecular and functional roles of duodenal cytochrome B (Dcytb) in iron metabolism. Blood Cells Mol. Dis. 2002; 29:356-360. [PubMed: 12547225]

31. Farcich EA, Morgan EH. Diminished iron acquisition by cells and tissues of Belgrade laboratory rats. Am. J. Physiol. Regul. Integr. Comp. Physiol. 1992; 262:R220-R224.

32. Farcich EA, Morgan EH. Uptake of transferrin-bound and nontransferrin-bound iron by reticulocytes from the Belgrade laboratory rat: comparison withWistar rat transferrin and reticulocytes. Am. J. Hematol. 1992; 39:9-14. [PubMed: 1536148]

33. Garrick MD, Gniecko K, Liu Y, Cohan DS, Garrick LM. Transferrin and the transferrin cycle in Belgrade rat reticulocytes. J. Biol. Chem. 1993; 268:14867-14874. [PubMed: 8325865]

34. Garrick MD, Scott D, Kulju D, Romano MA, Dolan KG, Garrick LM. Evidence for and consequences of chronic heme deficiency in Belgrade rat reticulocytes. Biochim. Biophys. Acta. 1999; 1449:125-136. [PubMed: 10082971]

35. Su MA, Trenor CC, Fleming JC, Fleming MD, Andrews NC. The G185R mutation disrupts function of the iron transporter Nramp2. Blood. 1998; 92:2157-2163. [PubMed: 9731075]

36. Gruenheid S, Canonne-Hergaux F, Gauthier S, Hackam DJ, Grinstein S, Gros P. The iron transport protein NRAMP2 is an integral membrane glycoprotein that colocalizes with transferrin in recycling endosomes. J. Exp. Med. 1999; 189:831-841. [PubMed: 10049947]

37. Iolascon A, d'Apolito M, Servedio V, Cimmino F, Piga A, Camaschella C. Microcytic anemia and hepatic iron overload in a child with compound heterozygous mutations in DMT1 (SCL11A2). Blood. 2006; 107:349-354. [PubMed: 16160008]

38. Mims MP, Guan Y, Pospisilova D, Priwitzerova M, Indrak K, et al. Identification of a human mutation of DMT1 in a patient with microcytic anemia and iron overload. Blood. 2005; 105:13371342. [PubMed: 15459009] 
39. Beaumont C, Delaunay J, Hetet G, Grandchamp B, de Montalembert M, Tchernia G. Two new human DMT1 gene mutations in a patient with microcytic anemia, low ferritinemia, and liver iron overload. Blood. 2006; 107:4168-4170. [PubMed: 16439678]

40. Blanco E, Kannengiesser C, Grandchamp B, Tasso M, Beaumont C. Not all DMT1 mutations lead to iron overload. Blood Cells Mol. Dis. 2009; 43:199-201. [PubMed: 19553145]

41. Lambe T, Simpson RJ, Dawson S, Bouriez-Jones T, Crockford TL, et al. Identification of a Steap3 endosomal targeting motif essential for normal iron metabolism. Blood. 2009; 113:1805-1808. [PubMed: 18955558]

42. Gunshin H, Fujiwara Y, Custodio AO, Direnzo C, Robine S, Andrews NC. Slc11a2 is required for intestinal iron absorption and erythropoiesis but dispensable in placenta and liver. J. Clin. Investig. 2005; 115:1258-1266. [PubMed: 15849611]

43. Gutierrez JA, Wessling-Resnick M. Molecular mechanisms of iron transport. Crit. Rev. Eukaryot. Gene Expr. 1996; 6:1-14. [PubMed: 8882304]

44. Batey RG, Lai Chung Fong P, Shamir S, Sherlock S. A non-transferrin-bound serum iron in idiopathic hemochromatosis. Dig. Dis. Sci. 1980; 25:340-346. [PubMed: 7371472]

45. Berger HM, Mumby S, Gutteridge JM. Ferrous ions detected in iron-overloaded cord blood plasma from preterm and term babies: implications for oxidative stress. Free Radic. Res. 1995; 22:555559. [PubMed: 7543335]

46. Evans PJ, Evans RW, Bomford A, Williams R, Halliwell B. Metal ions catalytic for free radical reactions in the plasma of patients with fulminant hepatic failure. Free Radic. Res. 1994; 20:139144. [PubMed: 8019638]

47. Carmine TC, Evans P, Bruchelt G, Evans R, Handgretinger R, et al. Presence of iron catalytic for free radical reactions in patients undergoing chemotherapy: implications for therapeutic management. Cancer Lett. 1995; 94:219-226. [PubMed: 7543367]

48. Gutteridge JM. Bleomycin-detectable iron in knee-joint synovial fluid from arthritic patients and its relationship to the extracellular antioxidant activities of caeruloplasmin, transferrin and lactoferrin. Biochem. J. 1987; 245:415-421. [PubMed: 2444216]

49. Gutteridge JM. Ferrous ions detected in cerebrospinal fluid by using bleomycin andDNAdamage. Clin. Sci. 1992; 82:315-320. [PubMed: 1372200]

50. Zhao H, Eide D. The yeast $Z R T 1$ gene encodes the zinc transporter protein of a high-affinity uptake system induced by zinc limitation. Proc. Natl. Acad. Sci. USA. 1996; 93:2454-2458. [PubMed: 8637895]

51. Zhao H, Eide D. The ZRT2 gene encodes the low affinity zinc transporter in Saccharomyces cerevisiae. J. Biol. Chem. 1996; 271:23203-23210. [PubMed: 8798516]

52. Eide D, Broderius M, Fett J, Guerinot ML. A novel iron-regulated metal transporter from plants identified by functional expression in yeast. Proc. Natl. Acad. Sci. USA. 1996; 93:5624-5628. [PubMed: 8643627]

53. Liuzzi JP, Aydemir F, Nam H, Knutson MD, Cousins RJ. Zip14 (Slc39a14) mediates nontransferrin- bound iron uptake into cells. Proc. Natl. Acad. Sci. USA. 2006; 103:13612-13617. [PubMed: 16950869]

54. Pinilla-Tenas JJ, Sparkman BK, Shawki A, Illing AC, Mitchell CJ, et al. Zip14 is a complex broadscope metal-ion transporter whose functional properties support roles in the cellular uptake of zinc and nontransferrin-bound iron. Am. J. Physiol. Cell Physiol. 2011; 301:C862-C871. [PubMed: 21653899]

55. Taylor KM, Nicholson RI. The LZT proteins; the LIV-1 subfamily of zinc transporters. Biochim. Biophys. Acta. 2003; 1611:16-30. [PubMed: 12659941]

56. Hallberg L. Does calcium interfere with iron absorption? AmJClin. Nutr. 1998; 68:3-4.

57. Morgan EH. Membrane transport of non-transferrin-bound iron by reticulocytes. Biochim. Biophys. Acta. 1988; 943:428-439. [PubMed: 3415985]

58. Hemmaplardh D, Morgan EH. The role of calcium in transferrin and iron uptake by reticulocytes. Biochim. Biophys. Acta. 1977; 468:423-436. [PubMed: 406921]

59. Oudit GY, Sun H, Trivieri MG, Koch SE, Dawood F, et al. L-type $\mathrm{Ca}^{2+}$ channels provide a major pathway for iron entry into cardiomyocytes in iron-overload cardiomyopathy. Nat. Med. 2003; 9:1187-1194. [PubMed: 12937413] 
60. Chattipakorn N, Kumfu S, Fucharoen S, Chattipakorn S. Calcium channels and iron uptake into the heart. World J. Cardiol. 2011; 3:215-218. [PubMed: 21860702]

61. Winegar BD, Kelly R, Lansman JB. Block of current through single calcium channels by Fe, Co, and Ni: location of the transition metal binding site in the pore. J. Gen. Physiol. 1991; 97:351-367. [PubMed: 1849961]

62. Shawki A, Mackenzie B. Interaction of calcium with the human divalent metal-ion transporter-1. Biochem. Biophys. Res. Commun. 2010; 393:471-475. [PubMed: 20152801]

63. Xu H, Jin J, DeFelice LJ, Andrews NC, Clapham DE. A spontaneous, recurrent mutation in divalent metal transporter-1 exposes a calcium entry pathway. PLoS Biol. 2004; 2:E50. [PubMed: 15024413]

64. Abe K, Puertollano R. Role of TRP channels in the regulation of the endosomal pathway. Physiology. 2011; 26:14-22. [PubMed: 21357899]

65. Donovan A, Brownlie A, Zhou Y, Shepard J, Pratt SJ, et al. Positional cloning of zebrafish ferroportin1 identifies a conserved vertebrate iron exporter. Nature. 2000; 403:776-781. [PubMed: 10693807]

66. McKie AT, Marciani P, Rolfs A, Brennan K, Wehr K, et al. A novel duodenal iron-regulated transporter, IREG1, implicated in the basolateral transfer of iron to the circulation. Mol. Cell. 2000; 5:299-309. [PubMed: 10882071]

67. Abboud S, Haile DJ. A novel mammalian iron-regulated protein involved in intracellular iron metabolism. J. Biol. Chem. 2000; 275:19906-19912. [PubMed: 10747949]

68. Muckenthaler M, Roy CN, Custodio AO, Minana B, deGraaf J, et al. Regulatory defects in liver and intestine implicate abnormal hepcidin and Cybrd1 expression in mouse hemochromatosis. Nat. Genet. 2003; 34:102-107. [PubMed: 12704390]

69. Montosi G, Donovan A, Totaro A, Garuti C, Pignatti E, et al. Autosomal-dominant hemochromatosis is associated with a mutation in the ferroportin (SLC11A3) gene. J. Clin. Investig. 2001; 108:619-623. [PubMed: 11518736]

70. McKie AT, Barlow DJ. The SLC40 basolateral iron transporter family (IREG1/ferroportin/MTP1). Pflüg. Arch. 2004; 447:801-806.

71. Knutson MD, Oukka M, Koss LM, Aydemir F, Wessling-Resnick M. Iron release from macrophages after erythrophagocytosis is up-regulated by ferroportin 1 overexpression and downregulated by hepcidin. Proc. Natl. Acad. Sci. USA. 2005; 102:1324-1328. [PubMed: 15665091]

72. Yamaguchi T, Sano K, Takakura K, Saito I, Shinohara Y, et al. Ebselen in acute ischemic stroke: a placebo-controlled, double-blind clinical trial. Stroke. 1998; 29:12-17. [PubMed: 9445321]

73. Parnham M, Sies H. Ebselen: prospective therapy for cerebral ischaemia. Expert Opin. Investig. Drugs. 2000; 9:607-619.

74. Schewe T. Molecular actions of ebselen—an antiinflammatory antioxidant. Gen. Pharmacol. 1995; 26:1153-1169. [PubMed: 7590103]

75. Zhao R, Holmgren A. A novel antioxidant mechanism of ebselen involving ebselen diselenide, a substrate of mammalian thioredoxin and thioredoxin reductase. J. Biol. Chem. 2002; 277:3945639462. [PubMed: 12177067]

76. Zhao R, Masayasu H, Holmgren A. Ebselen: a substrate for human thioredoxin reductase strongly stimulating its hydroperoxide reductase activity and a superfast thioredoxin oxidant. Proc. Natl. Acad. Sci. USA. 2002; 99:8579-8584. [PubMed: 12070343]

77. Davis MT, Bartfay WJ. Ebselen decreases oxygen free radical production and iron concentrations in the hearts of chronically iron-overloaded mice. Biol. Res. Nurs. 2004; 6:37-45. [PubMed: 15186706]

78. Wetli HA, Buckett PD, Wessling-Resnick M. Small-molecule screening identifies the selanazal drug ebselen as a potent inhibitor of DMT1-mediated iron uptake. Chem. Biol. 2006; 13:965-972. [PubMed: 16984886]

79. Petrat F, de Groot H, Sustmann R, Rauen U. The chelatable iron pool in living cells: a methodically defined quantity. Biol. Chem. 2002; 383:489-502. [PubMed: 12033438]

80. Petrat F, Paluch S, Dogruoz E, Dorfler P, Kirsch M, et al. Reduction of Fe(III) ions complexed to physiological ligands by lipoyl dehydrogenase and other flavoenzymes in vitro: implications for an 
enzymatic reduction of Fe(III) ions of the labile iron pool. J. Biol. Chem. 2003; 278:46403-46413. [PubMed: 12963736]

81. Savigni DL, Morgan EH. Mediation of iron uptake and release in erythroid cells by photodegradation products of nifedipine. Biochem. Pharmacol. 1996; 51:1701-1709. [PubMed: 8687485]

82. Savigni DL, Wege D, Cliff GS, Meesters ML, Morgan EH. Iron and transition metal transport into erythrocytes mediated by nifedipine degradation products and related compounds. Biochem. Pharmacol. 2003; 65:1215-1226. [PubMed: 12694863]

83. Ludwiczek S, Theurl I, Muckenthaler MU, Jakab M, Mair SM, et al. $\mathrm{Ca}^{2+}$ channel blockers reverse iron overload by a new mechanism via divalent metal transporter-1. Nat. Med. 2007; 13:448-454. [PubMed: 17293870]

84. Mackenzie B, Shawki A, Ghio AJ, Stonehuerner JD, Zhao L, et al. Calcium-channel blockers do not affect iron transport mediated by divalent metal-ion transporter-1. Blood. 2010; 115:41484149. [PubMed: 20489062]

85. Brown JX, Buckett PD, Wessling-Resnick M. Identification of small molecule inhibitors that distinguish between non-transferrin bound iron uptake and transferrin-mediated iron transport. Chem. Biol. 2004; 11:407-416. [PubMed: 15123270]

86. Buckett PD, Wessling-Resnick M. Small molecule inhibitors of divalent metal transporter-1. Am. J. Physiol. Gastrointest. Liver Physiol. 2009; 296:G798-G804. [PubMed: 19179627]

87. Lane DJ, Robinson SR, Czerwinska H, Bishop GM, Lawen A. Two routes of iron accumulation in astrocytes: ascorbate-dependent ferrous iron uptake via the divalent metal transporter (DMT1) plus an independent route for ferric iron. Biochem. J. 2010; 432:123-132. [PubMed: 20819077]

88. Moos T, Rosengren Nielsen T, Skjorringe T, Morgan EH. Iron trafficking inside the brain. J. Neurochem. 2007; 103:1730-1740. [PubMed: 17953660]

89. Burdo JR, Menzies SL, Simpson IA, Garrick LM, Garrick MD, et al. Distribution of divalent metal transporter 1 and metal transport protein 1 in the normal and Belgrade rat. J. Neurosci. Res. 2001; 66:1198-1207. [PubMed: 11746453]

90. Song N, Jiang H, Wang J, Xie JX. Divalent metal transporter 1 up-regulation is involved in the 6hydroxydopamine-induced ferrous iron influx. J. Neurosci. Res. 2007; 85:3118-3126. [PubMed: 17663481]

91. Klausner RD, Van Renswoude J, Ashwell G, Kempf C, Schechter AN, et al. Receptor-mediated endocytosis of transferrin in K562 cells. J. Biol. Chem. 1983; 258:4715-4724. [PubMed: 6300098]

92. Kirkham M, Parton RG. Clathrin-independent endocytosis: new insights into caveolae and noncaveolar lipid raft carriers. Biochim. Biophys. Acta. 2005; 1746:349-363. [PubMed: 16440447]

93. Bickel PE, Scherer PE, Schnitzer JE, Oh P, Lisanti MP, Lodish HF. Flotillin and epidermal surface antigen define a new family of caveolae-associated integral membrane proteins. J. Biol. Chem. 1997; 272:13793-13802. [PubMed: 9153235]

94. Morgan EH. Inhibition of reticulocyte iron uptake by $\mathrm{NH}_{4} \mathrm{Cl}$ and $\mathrm{CH}_{3} \mathrm{NH}_{2}$. Biochim. Biophys. Acta. 1981; 642:119-134. [PubMed: 7225374]

95. Ciechanover A, Schwartz AL, Dautry-Varsat A, Lodish HF. Kinetics of internalization and recycling of transferrin and the transferrin receptor in a human hepatoma cell line: effect of lysosomotropic agents. J. Biol. Chem. 1983; 258:9681-9689. [PubMed: 6309781]

96. Glass J, Nunez MT. Amines as inhibitors of iron transport in rabbit reticulocytes. J. Biol. Chem. 1986; 261:8298-8302. [PubMed: 3013846]

97. Nieland TJ, Feng Y, Brown JX, Chuang TD, Buckett PD, et al. Chemical genetic screening identifies sulfonamides that raise organellar $\mathrm{pH}$ and interfere with membrane traffic. Traffic. 2004; 5:478-492. [PubMed: 15180825]

98. Weisz OA. Acidification and protein traffic. Int. Rev. Cytol. 2003; 226:259-319. [PubMed: 12921239]

99. Park CH, Valore EV, Waring AJ, Ganz T. Hepcidin, a urinary antimicrobial peptide synthesized in the liver. J. Biol. Chem. 2001; 276:7806-7810. [PubMed: 11113131] 
100. Ganz T. Hepcidin, a key regulator of iron metabolism and mediator of anemia of inflammation. Blood. 2003; 102:783-788. [PubMed: 12663437]

101. Collins JF, Wessling-Resnick M, Knutson MD. Hepcidin regulation of iron transport. J. Nutr. 2008; 138:2284-2288. [PubMed: 18936232]

102. Roetto A, Papanikolaou G, Politou M, Alberti F, Girelli D, et al. Mutant antimicrobial peptide hepcidin is associated with severe juvenile hemochromatosis. Nat. Genet. 2003; 33:21-22. [PubMed: 12469120]

103. Piperno A, Girelli D, Nemeth E, Trombini P, Bozzini C, et al. Blunted hepcidin response to oral iron challenge in HFE-related hemochromatosis. Blood. 2007; 110:4096-4100. [PubMed: 17724144]

104. Beaumont C, Delaby C. Recycling iron in normal and pathological states. Semin. Hematol. 2009; 46:328-338. [PubMed: 19786201]

105. Girelli D, Pasino M, Goodnough JB, Nemeth E, Guido M, et al. Reduced serum hepcidin levels in patients with chronic hepatitis C. J. Hepatol. 2009; 51:845-852. [PubMed: 19729219]

106. Krause A, Neitz S, Magert HJ, Schulz A, Forssmann WG, et al. LEAP-1, a novel highly disulfide-bonded human peptide, exhibits antimicrobial activity. FEBS Lett. 2000; 480:147-150. [PubMed: 11034317]

107. Nemeth E, Tuttle MS, Powelson J, Vaughn MB, Donovan A, et al. Hepcidin regulates cellular iron efflux by binding to ferroportin and inducing its internalization. Science. 2004; 306:2090 2093. [PubMed: 15514116]

108. Knutson MD, Vafa MR, Haile DJ, Wessling-Resnick M. Iron loading and erythrophagocytosis increase ferroportin 1 (FPN1) expression in J774 macrophages. Blood. 2003; 102:4191-4197. [PubMed: 12907459]

109. Delaby C, Pilard N, Goncalves AS, Beaumont C, Canonne-Hergaux F. Presence of the iron exporter ferroportin at the plasma membrane of macrophages is enhanced by iron loading and down-regulated by hepcidin. Blood. 2005; 106:3979-3984. [PubMed: 16081696]

110. Laftah AH, Ramesh B, Simpson RJ, Solanky N, Bahram S, et al. Effect of hepcidin on intestinal iron absorption in mice. Blood. 2004; 103:3940-3944. [PubMed: 14751922]

111. Yamaji S, Sharp P, Ramesh B, Srai SK. Inhibition of iron transport across human intestinal epithelial cells by hepcidin. Blood. 2004; 104:2178-2180. [PubMed: 15178582]

112. Mena NP, Esparza A, Tapia V, Valdes P, Nunez MT. Hepcidin inhibits apical iron uptake in intestinal cells. Am. J. Physiol. Gastrointest. Liver Physiol. 2008; 294:G192-G198. [PubMed: 17962361]

113. Brasse-Lagnel C, Karim Z, Letteron P, Bekri S, Bado A, Beaumont C. Intestinal DMT1 cotransporter is down-regulated by hepcidin via proteasome internalization and degradation. Gastroenterology. 2011; 140:1261-1271. e1. [PubMed: 21199652]

114. Braun V, Killmann H. Bacterial solutions to the iron-supply problem. Trends Biochem. Sci. 1999; 24:104-109. [PubMed: 10203757]

115. Goetz DH, Holmes MA, Borregaard N, Bluhm ME, Raymond KN, Strong RK. The neutrophil lipocalin NGAL is a bacteriostatic agent that interferes with siderophore-mediated iron acquisition. Mol. Cell. 2002; 10:1033-1043. [PubMed: 12453412]

116. Bao G, Clifton M, Hoette TM, Mori K, Deng SX, et al. Iron traffics in circulation bound to a siderocalin (Ngal)-catechol complex. Nat. Chem. Biol. 2010; 6:602-609. [PubMed: 20581821]

117. Devireddy LR, Hart DO, Goetz DH, Green MR. A mammalian siderophore synthesized by an enzyme with a bacterial homolog involved in enterobactin production. Cell. 2010; 141:10061017. [PubMed: 20550936]

118. Olivieri NF, Brittenham GM. Iron-chelating therapy and the treatment of thalassemia. Blood. 1997; 89:739-761. [PubMed: 9028304]

119. Kalinowski DS, Richardson DR. The evolution of iron chelators for the treatment of iron overload disease and cancer. Pharmacol. Rev. 2005; 57:547-583. [PubMed: 16382108]

120. Aouad F, Florence A, Zhang Y, Collins F, Henry C, et al. Evaluation of new iron chelators and their therapeutic potential. Inorg. Chim. Acta. 2002; 339:470-480.

121. Cappellini MD, Pattoneri P. Oral iron chelators. Annu. Rev. Med. 2009; 60:25-38. [PubMed: 19630568] 
122. Motekaitis RJ, Martell AE. Stabilities of the iron(III) chelates of 1,2-dimethyl-3-hydroxy-4pyridinone and related ligands. Inorg. Chim. Acta. 1991; 183:71-80.

123. Nick H, Acklin P, Lattmann R, Buehlmayer P, Hauffe S, et al. Development of tridentate iron chelators: from desferrithiocin to ICL670. Curr. Med. Chem. 2003; 10:1065-1076. [PubMed: 12678677]

124. Hershko C, Konijn AM, Nick HP, Breuer W, Cabantchik ZI, Link G. ICL670A: a new synthetic oral chelator: evaluation in hypertransfused rats with selective radioiron probes of hepatocellular and reticuloendothelial iron stores and in iron-loaded rat heart cells in culture. Blood. 2001; 97:1115-1122. [PubMed: 11159545]

125. Cappellini MD, Cohen A, Piga A, Bejaoui M, Perrotta S, et al. A phase 3 study of deferasirox (ICL670), a once-daily oral iron chelator, in patients with $\beta$-thalassemia. Blood. 2006; 107:34553462. [PubMed: 16352812]

126. Piga A, Galanello R, Forni G, Cappellini M, Origa R, et al. Randomized phase II trial of deferasirox (Exjade, ICL670), a once-daily, orally-administered iron chelator, in comparison to deferoxamine in thalassemia patients with transfusional iron overload. Haematologica. 2006; 91:873-880. [PubMed: 16818273]

127. Galanello R, Piga A, Forni GL, Bertrand Y, Foschini ML, et al. Phase II clinical evaluation of deferasirox, a once-daily oral chelating agent, in pediatric patients with $\beta$-thalassemia major. Haematologica. 2006; 91:1343-1351. [PubMed: 17018383]

128. Vichinsky E, Onyekwere O, Porter J, Swerdlow P, Eckman J, et al. A randomised comparison of deferasirox versus deferoxamine for the treatment of transfusional iron overload in sickle cell disease. Br. J. Haematol. 2007; 136:501-508. [PubMed: 17233848]

129. Porter J, Galanello R, Saglio G, Neufeld EJ, Vichinsky E, et al. Relative response of patients with myelodysplastic syndromes and other transfusion-dependent anaemias to deferasirox (ICL670): a 1-yr prospective study. EurJHaematol. 2008; 80:168-176.

130. Kontoghiorghes GJ, Eracleous E, Economides C, Kolnagou A. Advances in iron overload therapies. Prospects for effective use of deferiprone (L1), deferoxamine, the new experimental chelators ICL670, GT56-252, L1NA11 and their combinations. Curr. Med. Chem. 2005; 12:2663-2681. [PubMed: 16305464]

131. Kontoghiorghes GJ, Barr J, Nortey P, Sheppard L. Selection of a new generation of orally active a-ketohydroxypyridine iron chelators intended for use in the treatment of iron overload. Am. J. Hematol. 1993; 42:340-349. [PubMed: 8493983]

132. Lederman HM, Cohen A, Lee JW, Freedman MH, Gelfand EW. Deferoxamine: a reversible Sphase inhibitor of human lymphocyte proliferation. Blood. 1984; 64:748-753. [PubMed: 6380622]

133. Seligman PA, Schleicher RB, Siriwardana G, Domenico J, Gelfand EW. Effects of agents that inhibit cellular iron incorporation on bladder cancer cell proliferation. Blood. 1993; 82:16081617. [PubMed: 8364209]

134. Noulsri E, Richardson DR, Lerdwana S, Fucharoen S, Yamagishi T, et al. Antitumor activity and mechanism of action of the iron chelator, Dp44mT, against leukemic cells. Am. J. Hematol. 2009; 84:170-176. [PubMed: 19140186]

135. Richardson DR, Sharpe PC, Lovejoy DB, Senaratne D, Kalinowski DS, et al. Dipyridyl thiosemicarbazone chelators with potent and selective antitumor activity form iron complexes with redox activity. J. Med. Chem. 2006; 49:6510-6521. [PubMed: 17064069]

136. Gojo I, Tidwell ML, Greer J, Takebe N, Seiter K, et al. Phase I and pharmacokinetic study of Triapine ${ }^{\circledR}$, a potent ribonucleotide reductase inhibitor, in adults with advanced hematologic malignancies. Leuk. Res. 2007; 31:1165-1173. [PubMed: 17324462]

137. Knox JJ, Hotte SJ, Kollmannsberger C, Winquist E, Fisher B, Eisenhauer EA. Phase II study of Triapine $®$ in patients with metastatic renal cell carcinoma: a trial of the National Cancer Institute of Canada Clinical Trials Group (NCIC IND.161). Investig. New Drugs. 2007; 25:471-477. [PubMed: 17393073]

138. Mackenzie MJ, Saltman D, Hirte H, Low J, Johnson C, et al. A Phase II study of 3aminopyridine-2-carboxaldehyde thiosemicarbazone (3-AP) and gemcitabine in advanced 
pancreatic carcinoma. A trial of the Princess Margaret hospital Phase II consortium. Investig. New Drugs. 2007; 25:553-658. [PubMed: 17585372]

139. Murren J, Modiano M, Clairmont C, Lambert P, Savaraj N, et al. Phase I and pharmacokinetic study of Triapine, a potent ribonucleotide reductase inhibitor, administered daily for five days in patients with advanced solid tumors. Clin. Cancer Res. 2003; 9:4092-4100. [PubMed: 14519631]

140. Ma B, Goh BC, Tan EH, Lam KC, Soo R, et al. A multicenter phase II trial of 3-aminopyridine-2carboxaldehyde thiosemicarbazone (3-AP, Triapine) and gemcitabine in advanced non-small-cell lung cancer with pharmacokinetic evaluation using peripheral blood mononuclear cells. Investig. New Drugs. 2008; 26:169-173. [PubMed: 17851637]

141. Attia S, Kolesar J, Mahoney MR, Pitot HC, Laheru D, et al. A phase 2 consortium (P2C) trial of 3-aminopyridine-2-carboxaldehyde thiosemicarbazone (3-AP) for advanced adenocarcinoma of the pancreas. Investig. New Drugs. 2008; 26:369-379. [PubMed: 18278438]

142. Richardson DR, Tran EH, Ponka P. The potential of iron chelators of the pyridoxal isonicotinoyl hydrazone class as effective antiproliferative agents. Blood. 1995; 86:4295-4306. [PubMed: 7492790]

143. Richardson DR, Milnes K. The potential of iron chelators of the pyridoxal isonicotinoyl hydrazone class as effective antiproliferative agents II: the mechanism of action of ligands derived from salicylaldehyde benzoyl hydrazone and 2-hydroxy-1-naphthylaldehyde benzoyl hydrazone. Blood. 1997; 89:3025-3038. [PubMed: 9108424]

144. Lovejoy DB, Richardson DR. Novel "hybrid" iron chelators derived from aroylhydrazones and thiosemicarbazones demonstrate selective antiproliferative activity against tumor cells. Blood. 2002; 100:666-676. [PubMed: 12091363]

145. Yu Y, Kalinowski DS, Kovacevic Z, Siafakas AR, Jansson PJ, et al. Thiosemicarbazones from the old to new: iron chelators that are more than just ribonucleotide reductase inhibitors. J. Med. Chem. 2009; 52:5271-5294. [PubMed: 19601577]

146. Whitnall M, Howard J, Ponka P, Richardson DR. A class of iron chelators with a wide spectrum of potent antitumor activity that overcomes resistance to chemotherapeutics. Proc. Natl. Acad. Sci. USA. 2006; 103:14901-14906. [PubMed: 17003122]

147. Kalinowski DS, Sharpe PC, Bernhardt PV, Richardson DR. Design, synthesis, and characterization of new iron chelators with anti-proliferative activity: structure-activity relationships of novel thiohydrazone analogues. J. Med. Chem. 2007; 50:6212-6225. [PubMed: 17963372]

148. Li Z, Tanaka H, Galiano F, Glass J. Anticancer activity of the iron facilitator LS081. J. Exp. Clin. Cancer Res. 2011; 30:34. [PubMed: 21453502]

149. Daniels TR, Delgado T, Helguera G, Penichet ML. The transferrin receptor part II: targeted delivery of therapeutic agents into cancer cells. Clin. Immunol. 2006; 121:159-176. [PubMed: 16920030]

150. Daniels TR, Delgado T, Rodriguez JA, Helguera G, Penichet ML. The transferrin receptor part I: biology and targeting with cytotoxic antibodies for the treatment of cancer. Clin. Immunol. 2006; 121:144-158. [PubMed: 16904380]

151. Weaver M, Laske DW. Transferrin receptor ligand-targeted toxin conjugate (Tf-CRM107) for therapy of malignant gliomas. J. Neuro-Oncol. 2003; 65:3-13.

152. Kurz T, Gustafsson B, Brunk UT. Cell sensitivity to oxidative stress is influenced by ferritin autophagy. Free Radic. Biol. Med. 2011; 50:1647-1658. [PubMed: 21419217]

153. Komaki R, Lee JS, Kaplan B, Allen P, Kelly JF, et al. Randomized phase III study of chemoradiation with or without amifostine for patients with favorable performance status inoperable stage II-III nonsmall cell lung cancer: preliminary results. Semin. Radiat. Oncol. 2002; 12:46-49. [PubMed: 11917284]

154. Jatoi A, Thomas CR Jr. Esophageal cancer and the esophagus: challenges and potential strategies for selective cytoprotection of the tumor-bearing organ during cancer treatment. Semin. Radiat. Oncol. 2002; 12:62-67. [PubMed: 11917287]

155. Movsas B. Exploring the role of the radioprotector amifostine in locally advanced non-small cell lung cancer: Radiation Therapy Oncology Group trial 98-01. Semin. Radiat. Oncol. 2002; 12:4045. [PubMed: 11917283] 
156. Werner-Wasik M, Axelrod RS, Friedland DP, Hauck W, Rose LJ, et al. Phase II: trial of twice weekly amifostine in patients with non-small cell lung cancer treated with chemoradiotherapy. Semin. Radiat. Oncol. 2002; 12:34-39. [PubMed: 11917282]

157. Zoberi I, Wasserman TH, Chao KS. A prospective, nonrandomized study of the impact of amifostine on subsequent hypothyroidism in irradiated patients with head and neck cancers. Semin. Radiat. Oncol. 2002; 12:14-17. [PubMed: 11917278]

158. Small W Jr. The potential role of amifostine in the treatment of carcinoma of the uterine cervix: a review. Semin. Radiat. Oncol. 2002; 12:68-74. [PubMed: 11917288]

159. Werner-Wasik M, Langer C, Movsas B. Amifostine in chemoradiation therapy for non-small cell lung cancer: review of experience and design of a phase II trial assessing subcutaneous and intravenous bolus administration. Semin. Oncol. 2005; 32:S105-S108. [PubMed: 16015544]

160. Andreassen CN, Grau C, Lindegaard JC. Chemical radioprotection: a critical review of amifostine as a cytoprotector in radiotherapy. Semin. Radiat. Oncol. 2003; 13:62-72. [PubMed: 12520465]

161. Wilson RB. Iron dysregulation in Friedreich ataxia. Semin. Pediatr. Neurol. 2006; 13:166-175. [PubMed: 17101455]

162. Wong A, Yang J, Cavadini P, Gellera C, Lonnerdal B, et al. TheFriedreich's ataxia mutation confers cellular sensitivity to oxidant stress which is rescued by chelators of iron and calcium and inhibitors of apoptosis. Hum. Mol. Genet. 1999; 8:425-430. [PubMed: 9949201]

163. Ponka P, Borova J, Neuwirt J, Fuchs O. Mobilization of iron from reticulocytes. Identification of pyridoxal isonicotinoyl hydrazone as a new iron chelating agent. FEBS Lett. 1979; 97:317-321. [PubMed: 761636]

164. Richardson DR, Ponka P. Pyridoxal isonicotinoyl hydrazone and its analogs: potential orally effective iron-chelating agents for the treatment of iron overload disease. J. Lab. Clin. Med. 1998; 131:306-315. [PubMed: 9579383]

165. Youdim MB, Stephenson G, Ben Shachar D. Ironing iron out in Parkinson's disease and other neurodegenerative diseases with iron chelators: a lesson from 6-hydroxydopamine and iron chelators, desferal and VK-28. Ann. N. Y. Acad. Sci. 2004; 1012:306-325. [PubMed: 15105275]

166. Cherny RA, Atwood CS, Xilinas ME, Gray DN, Jones WD, et al. Treatment with a copper-zinc chelator markedly and rapidly inhibits $\beta$-amyloid accumulation in Alzheimer's disease transgenic mice. Neuron. 2001; 30:665-676. [PubMed: 11430801]

167. Rottkamp CA, Raina AK, Zhu X, Gaier E, Bush AI, et al. Redox-active iron mediates amyloid- $\beta$ toxicity. Free Radic. Biol. Med. 2001; 30:447-450. [PubMed: 11182300]

168. Duce JA, Tsatsanis A, Cater MA, James SA, Robb E, et al. Iron-export ferroxidase activity of $\beta$ amyloid precursor protein is inhibited by zinc in Alzheimer's disease. Cell. 2010; 142:857-867. [PubMed: 20817278]

169. Rogers JT, Randall JD, Cahill CM, Eder PS, Huang X, et al. An iron-responsive element type II in the 5'-untranslated region of the Alzheimer's amyloid precursor protein transcript. J. Biol. Chem. 2002; 277:45518-45528. [PubMed: 12198135]

170. Bandyopadhyay S, Huang X, Lahiri DK, Rogers JT. Novel drug targets based on metallobiology of Alzheimer's disease. Expert Opin. Ther. Targets. 2010; 14:1177-1197. [PubMed: 20942746]

171. Cahill CM, Lahiri DK, Huang X, Rogers JT. Amyloid precursor protein and asynuclein translation, implications for iron and inflammation in neurodegenerative diseases. Biochim. Biophys. Acta. 2009; 1790:615-628. [PubMed: 19166904]

172. Jiao Y, Wilkinson J IV, Di X, Wang W, Hatcher H, et al. Curcumin, a cancer chemopreventive and chemotherapeutic agent, is a biologically active iron chelator. Blood. 2009; 113:462-469. [PubMed: 18815282]

173. Hutchinson C, Bomford A, Geissler CA. The iron-chelating potential of silybin in patients with hereditary haemochromatosis. Eur. J. Clin. Nutr. 2010; 64:1239-1241. [PubMed: 20628405]

174. Dumont E, D'Arbigny P, Nouvelot A. Protection of polyunsaturated fatty acids against irondependent lipid peroxidation by a Ginkgo biloba extract (EGb 761). Methods Find. Exp. Clin. Pharmacol. 1995; 17:83-88. [PubMed: 7674702]

175. Preza GC, Ruchala P, Pinon R, Ramos E, Qiao B, et al. Minihepcidins are rationally designed small peptides that mimic hepcidin activity in mice and may be useful for the treatment of iron overload. J. Clin. Investig. 2011; 121:4880-4888. [PubMed: 22045566] 


\section{SUMMARY POINTS}

1. Several membrane-spanning transporters, channels, and proteins are involved in iron uptake and export. In the duodenum, dietary iron is transported through DMT1 into enterocytes and exits the enterocyte through ferroportin to enter systemic circulation. Iron is transported to peripheral tissues by $\mathrm{Tf}$ and undergoes receptor-mediated endocytosis after binding to TfR1. Iron exits endosomes through DMT1. Alternatively, other factors including Zip14, calcium channels, and TRPML1 may help mediate delivery of iron to cells. The uptake, export, and usage of iron requires a series of oxidation-reduction steps, including the specific transport factors hephaestin and Steap3.

2. Iron transport is inhibited or stimulated by a variety of chemical and naturally occurring compounds. Antioxidant molecules (ebselen and PDTC) decrease iron levels by antagonizing NTBI uptake by DMT1. In contrast, NTBI uptake was stimulated by the presence of nifedipine (and its photodegradation product) through the enhancement of DMT1 activity, but the precise mechanism remains controversial. Tf-bound iron uptake is inhibited by NSC306711/ferristatin through degradation of TfR1. The naturally occurring peptide hormone hepcidin inhibits iron export by inducing degradation of ferroportin in macrophages. It may play a different role by inhibiting DMT1 function in intestinal cells.

3. Iron chelation therapy is being tested and used as a therapeutic for diseases including iron overload, several cancers, and neurodegenerative diseases. Treatment with DFO shows positive improvement in both iron overload and Alzheimer's disease. Through the chelation of iron, DFO treatment results in reduced levels of ROS in cells. Currently, deferasirox is approved for use in the treatment of transfusion-induced iron overload, with several clinical trials testing therapeutic value for a variety of anemias. Chelation therapy for cancer works via two mechanisms: Removal of iron arrests cell proliferation at the $\mathrm{G}_{1}$ / $\mathrm{S}$ phase of the cell cycle, and a redox-active chelator can induce generation of ROS that are toxic to cancer cells, leading to apoptosis.

4. The future study of iron transport is expanding through studies of natural products including curcumin, silybin, and Ginkgo biloba. These and other avenues provided by small-molecule screening help further the study of iron transport and possibly treat diseases. 


\section{Redox-coupled uptake}

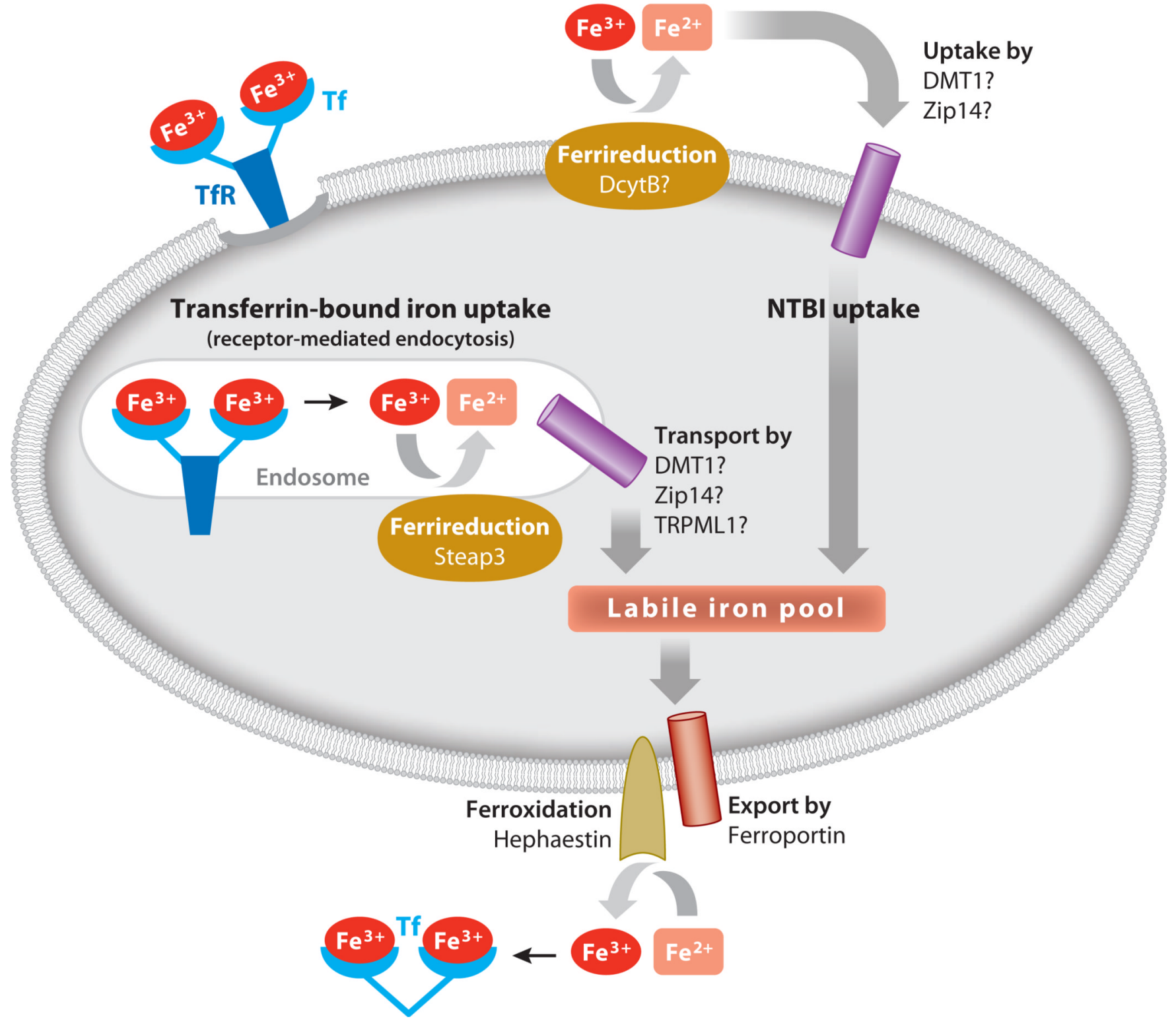

Figure 1.

Mechanisms of cellular iron import and export. $\mathrm{Fe}^{3+}-\mathrm{Tf}$ binds to TfR on the cell surface and undergoes receptor-mediated endocytosis. The released $\mathrm{Fe}^{3+}$ is reduced to $\mathrm{Fe}^{2+}$ by Steap3 within the endosome. Iron exits the endosome and enters the labile iron pool. Alternatively, NTBI is reduced at the cell surface prior to cellular uptake. Cellular iron $\left(\mathrm{Fe}^{2+}\right)$ exits through ferroportin and is oxidized to $\mathrm{Fe}^{3+}$ and transported bound to Tf. Abbreviations: DcytB, duodenal cytochrome B; DMT1, divalent metal transporter-1; NTBI, non-transferrin-bound iron; Tf, transferrin; TfR, transferrin receptor; TRPML1, transient receptor potential mucolipin 1; Zip14, ZRT/IRT-like protein 14. 


\section{Table 1}

Inhibitors and stimulators of iron transport pathways

\begin{tabular}{l|l|l}
\hline Transporter & Transport pathway & Inhibitor/stimulator \\
\hline TfR1/TfR2 & Tf-bound endocytic uptake & Chloroquine, $\mathrm{NH}_{4} \mathrm{Cl}$, weak bases NSC306711/Ferristatin Sulfonamides \\
\hline DMT1 (Slc11a2) & Intestinal uptake, Tf-bound endocytic uptake & $\begin{array}{l}\text { Ebselen, PDTC, antioxidants Nifedipine? NSC306711/Ferristatin, } \\
\text { polysulfonated dyes }\end{array}$ \\
\hline Zip14 (Slc39a14) & NTBI uptake, Tf-bound endocytic uptake & $? ?$ \\
\hline L-type channels & NTBI uptake by cardiomyocytes & Nifedipine \\
\hline TRPML1 & Lysosome iron export & $? ?$ \\
\hline Ferroportin & Intestinal/macrophage iron export & Hepcidin Mini-hepcidin (175) \\
\hline
\end{tabular}

Abbreviations: NTBI, non-transferrin-bound iron; PDTC, pyrrolidinedithiocarbamate; Tf, transferrin; TfR, transferrin receptor; TRPML1, transient receptor potential mucolipin 1; Zip14, ZRT/IRT-like protein 14. 
Table 2

Chemical properties and structures of iron chelators

\begin{tabular}{|c|c|c|}
\hline Chelator & Electron-donating groups & Structure \\
\hline DFO & $\begin{array}{l}\text { Hexadentate }(6) \\
1: 1, \text { chelator:iron }\end{array}$ & \\
\hline Deferiprone & $\begin{array}{l}\text { Bidentate (2) } \\
\text { 3:1, chelator:iron }\end{array}$ & \\
\hline Deferasirox & $\begin{array}{l}\text { Tridentate (3) } \\
\text { 2:1, chelator:iron }\end{array}$ & \\
\hline Deferitrin & $\begin{array}{l}\text { Tridentate }(3) \\
2: 1, \text { chelator:iron }\end{array}$ & \\
\hline L1NA11 & $\begin{array}{l}\text { Bidentate (2) } \\
3: 1 \text {, chelator:iron }\end{array}$ & \\
\hline
\end{tabular}

